Article

\title{
Intermittent Hypoxic Exposure with High Dose of Arginine Impact on Circulating Mediators of Tissue Regeneration
}

\author{
Agnieszka Zembron-Lacny ${ }^{1}{ }^{10}$, Artur Gramacki ${ }^{2}$, Edyta Wawrzyniak-Gramacka ${ }^{1}$, \\ Anna Tylutka ${ }^{1}$, Natalia Hertmanowska ${ }^{1}{ }^{\circledR}$, Anna Kasperska ${ }^{3}$ and Miłosz Czuba ${ }^{1,4, *}$ \\ 1 Department of Applied and Clinical Physiology, Collegium Medicum University of Zielona Gora, \\ 65-417 Zielona Gora, Poland; a.zembron-lacny@cm.uz.zgora.pl (A.Z.-L.); \\ e.gramacka@cm.uz.zgora.pl (E.W.-G.); a.tylutka@cm.uz.zgora.pl (A.T.); \\ n.hertmanowska@cm.uz.zgora.pl (N.H.) \\ 2 Faculty of Computer, Electrical and Control Engineering. Institute of Control and Computation Engineering \\ University of Zielona Gora, 65-417 Zielona Gora, Poland; a.gramacki@issi.uz.zgora.pl \\ 3 Department of Physiology, University School of Physical Education in Poznan, 61-871 Poznan, Poland; \\ a.kasperska@gmail.com \\ 4 Department of Kinesiology, Institute of Sport, 01-982 Warsaw, Poland \\ * Correspondence: m.czuba@cm.uz.zgora.pl; Tel.: +48-792-881-377
}

Received: 22 May 2020; Accepted: 24 June 2020; Published: 29 June 2020

\begin{abstract}
Intermittent exposure to hypoxia (IHE) increases production of reactive oxygen and nitrogen species which, as signalling molecules, participate in tissue injury-repair-regeneration cascade. The process is also stimulated by arginine whose bioavailability is a limiting factor for NO synthesis. The effects of IHE in combination with arginine (Arg) intake on myogenesis and angiogenesis mediators were examined in a randomized and placebo-controlled trial. Blood samples were collected from 38 elite athletes on the 1st, 7 th and 14th days during the training camp. The oral doses of arginine ( $2 \times 6 \mathrm{~g} /$ day) and/or IHE using hypoxicator GO2Altitude (IHE and Arg/IHE) were applied. Serum $\mathrm{NO}$ and $\mathrm{H}_{2} \mathrm{O}_{2}$ concentrations increased significantly and were related to muscle damage (CK activity $>900 \mathrm{IU} / \mathrm{mL}$ ) in IHE and Arg/IHE compared to placebo. The changes in $\mathrm{NO}$ and $\mathrm{H}_{2} \mathrm{O}_{2}$ elevated the levels of circulating growth factors such as HGF, IHG-1, PDGF ${ }^{\mathrm{BB}}$, BDNF, VEGF and EPO. Modification of the lipid profile, especially reduced non-HDL, was an additional beneficial effect of hypoxic exposure with arginine intake. Intermittent hypoxic exposure combined with high-dose arginine intake was demonstrated to affect circulating mediators of injury-repair-regeneration. Therefore, a combination of IHE and arginine seems to be a potential therapeutic and non-pharmacological method to modulate the myogenesis and angiogenesis in elite athletes.
\end{abstract}

Keywords: nitric oxide; hydrogen peroxide; growth factors; muscle damage; athletes

\section{Introduction}

The proliferation of satellite cells and vascularization are the essential processes in the regeneration of injured skeletal muscles. Myogenesis and angiogenesis are a prerequisite for the subsequent morphological and functional healing of the injured muscle. This, in turn, leads to rebuilding of the damaged myocytes and vessels, restoration of the blood flow and oxygen supply to the tissue. Nitric oxide (NO) plays a key role in repair response by inducing gene expression for several growth factors such as FGF, VEGF, IGF-1, HGF, PDGF ${ }^{\mathrm{BB}}$ and BDNF, which are extracellular signals regulating the functions of the muscular, vascular and nervous systems. NO is produced from L-arginine by three 
isoenzymes called nitric oxide synthases (NOS), all present in skeletal muscles. While neuronal NOS (nNOS) and endothelial NOS (eNOS) are isoforms expressed constitutively, inducible NOS (iNOS) is mainly expressed during inflammatory response. NO generation can be modulated by intense physical training (physiological hypoxia), altitude training or training in hypoxic conditions, NO donors or NO precursors such as L-arginine [1-3].

Over recent years, intermittent hypoxic exposure (IHE) has been introduced into sport. IHE is a method by which athletes are exposed to short bouts of severe hypoxia $\left(9-12 \% \mathrm{O}_{2}\right)$, interspersed with periods of normal air. Available studies reported substantial improvement in sea level endurance and anaerobic performance after IHE [4-6]. Beside the effects that hypoxia exerts on physical performance, there is some evidence that IHE might be beneficial for vascular endothelial activity and muscle regenerative capacity $[7,8]$. Hypoxic exposure increases production of reactive nitrogen and oxygen species ( $\mathrm{NO}$ and $\mathrm{H}_{2} \mathrm{O}_{2}$ ) and affects metabolic pathways including mitochondrial respiration and biogenesis, apoptosis and, what has more recently been demonstrated, satellite cells proliferation. However, $\mathrm{NO}$ and $\mathrm{H}_{2} \mathrm{O}_{2}$ play a contradictory role in muscle regeneration and repair, i.e., in combination with growth factors, they lead to recovery of tissue function, whereas the local persistence of $\mathrm{NO}$ and $\mathrm{H}_{2} \mathrm{O}_{2}$ sustained by infiltrated neutrophils may cause further oxidative injury to differentiating myoblasts and myotubes, thereby delaying the complete health restoration $[9,10]$. So far, little is known on hypoxic exposure in combination with high arginine intake and their influence on the muscle injury, repair and regeneration. The typical dietary intake of L-arginine is set at approx. 3-8 g per day. Extracellular L-arginine can be rapidly taken up by endothelial cells and oxidized to NO. In a few clinical trials, intravenous (single dose of $30 \mathrm{~g}$ within $30 \mathrm{~min}$ ) or dietary administration of relatively large doses of L-arginine (15-16 g per day) has been shown to result in enhanced NO formation, especially in subjects with endothelial dysfunction [11]. L-arginine also participates in other metabolic pathways, which are independent of NO synthesis but essential for physical performance. For instance, as a potent hormone secretagogue, L-arginine increases plasma levels of insulin, glucagon, growth hormone, insulin-like growth factor 1 and catecholamines [12]. Additionally, L-arginine may be metabolized via arginase whose high concentrations are identified in healing wounds due to macrophage production. Arginase activity results in ornithine formation, which is a precursor for proline that serves as substrate for collagen synthesis. Therefore, arginine supplementation could have a multidirectional impact on tissue regenerative processes [13,14]. On the basis of the gathered data, the present study was designed to explain whether hypoxic-induced $\mathrm{NO}$ and $\mathrm{H}_{2} \mathrm{O}_{2}$ generation contributes to the release of oxi-inflammatory mediators regulating the injury-repair-regeneration of skeletal muscles and to check whether high-dose L-arginine intake enhances NO and growth factors production during intermittent hypoxic exposure.

\section{Materials and Methods}

\subsection{Subjects}

Forty elite male wrestlers, members of the national team, were observed during preparatory periods for the new competition season (endurance training 53\%, directed training $9 \%$ and special power training 38\%). Each athlete underwent a thorough screening, including a full medical evaluation in National Centre for Sports Medicine. A two-week washout period was introduced before the training camp to avoid any possible interference of other nutritional supplements in the measured biochemical markers. Exclusion criteria included serious orthopaedic injury $(n=3)$, nutrition supplements or medications $(n=2)$, dehydration $(n=2)$ and anaemia $(n=1)$ identified at any point of the entire observation. Eventually, thirty-two athletes met all the criteria and completed the whole experiment (Table 1). The athletes participated in a 14-day training camp at the National Olympic Sport Centre. Prior to the training camp, the athletes were randomly assigned in a double-blind manner to a control group (placebo; methylcellulose capsules: $2 \times 6$ g per day for 12 days), an arginine group (Arg; capsules: 
$2 \times 6$ g per day for 12 days), a hypoxia group (IHE) and an arginine with hypoxic exposure group (Arg/IHE).

Table 1. Anthropometrics and body composition (mean \pm SD).

\begin{tabular}{|c|c|c|c|c|c|}
\hline & $\begin{array}{c}\text { Control } \\
n=10\end{array}$ & $\begin{array}{c}\text { Arg } \\
n=7\end{array}$ & $\begin{array}{c}\text { IHE } \\
n=6\end{array}$ & $\begin{array}{c}\text { Arg/IHE } \\
n=9\end{array}$ & $\begin{array}{l}\text { Control vs. Arg } \\
\text { IHE Arg/IHE }\end{array}$ \\
\hline Age [yr.] & $24.6 \pm 3.0$ & $20.0 \pm 1.6$ & $22.8 \pm 2.6$ & $24.7 \pm 4.4$ & $\begin{array}{l}<0.05 \\
0.622 \\
0.999\end{array}$ \\
\hline Height [cm] & $173.6 \pm 8.8$ & $179.0 \pm 9.5$ & $181.2 \pm 7.3$ & $175.6 \pm 8.3$ & $\begin{array}{l}0.559 \\
0.320 \\
0.947\end{array}$ \\
\hline Weight [kg] & $81.4 \pm 21.8$ & $79.9 \pm 13.0$ & $97.1 \pm 22.7$ & $87.9 \pm 20.7$ & $\begin{array}{l}0.989 \\
0.560 \\
0.957\end{array}$ \\
\hline $\mathrm{BMI}\left[\mathrm{kg} / \mathrm{m}^{2}\right]$ & $26.6 \pm 4.5$ & $24.4 \pm 1.4$ & $29.3 \pm 5.2$ & $27.8 \pm 4.5$ & $\begin{array}{l}0.552 \\
0.773 \\
0.990\end{array}$ \\
\hline$\% \mathrm{FM}$ & $18.1 \pm 4.8$ & $9.3 \pm 3.0$ & $14.5 \pm 6.0$ & $21.3 \pm 6.5$ & $\begin{array}{l}<0.05 \\
0.844 \\
0.252\end{array}$ \\
\hline FM [kg] & $15.4 \pm 7.4$ & $7.6 \pm 3.2$ & $15.1 \pm 9.5$ & $19.3 \pm 10.8$ & $\begin{array}{l}0.355 \\
0.998 \\
0.569\end{array}$ \\
\hline FFM [kg] & $66.0 \pm 15.0$ & $72.3 \pm 10.6$ & $81.9 \pm 14.0$ & $67.2 \pm 11.5$ & $\begin{array}{l}0.952 \\
0.270 \\
0.996\end{array}$ \\
\hline
\end{tabular}

\footnotetext{
Abbreviations: Arg, arginine intake; IHE, intermittent hypoxic exposure; Arg/IHE, arginine intaken and intermittent hypoxic exposure; BMI, body mass index; FM, fat mass; FFM, fat-free mass. The significant differences in mean values between the groups (Control vs. Arg, Control vs. IHE, Control vs. Arg/IHE were assessed by the one-way ANOVA and Tukey's post hoc test.
}

Throughout the camp, all athletes lived at the same accommodation and followed the same training schedule, sleeping time and diet. Daily energy value of food offered on the menu did not exceed $5200 \mathrm{kcal}$, and the protein dose varied from 1.6 to $1.8 \mathrm{~g} / \mathrm{kg}$ of body mass. During the camp, the wrestlers consumed an isotonic sports drink Vitargo (osmolality $317 \mathrm{mOsm} / \mathrm{kg} \mathrm{H}_{2} \mathrm{O}$ ) or plain water. The dehydration level was assessed by Osmocheck calibrated in $\mathrm{mOsm} / \mathrm{kg} \mathrm{H} \mathrm{H}_{2} \mathrm{O}$ from 0 to 1500 mOsmols. All the subjects were informed of the aim of the study and signed a written consent to participate in the project. The protocol of the study was approved by the ethics committee at Medical University Poznan ( $\left.{ }^{\circ} 550 / 11\right)$, in accordance with the Helsinki Declaration.

\subsection{Arginine Supplementation}

The flavour and appearance of arginine capsules $(6 \mathrm{~g}$ capsules administered twice a day for 12 days) and placebo (methylcellulose capsules: $2 \times 6 \mathrm{~g}$ per day for 12 days) were indistinguishable for both the subjects and the investigators. The subjects were instructed to consume their supplement $1 \mathrm{~h}$ before the morning training and $1 \mathrm{~h}$ before the afternoon training for 12 days of the training camp (Figure 1). Arginine and placebo capsules were prepared by Nutrend (The Czech Republic). 


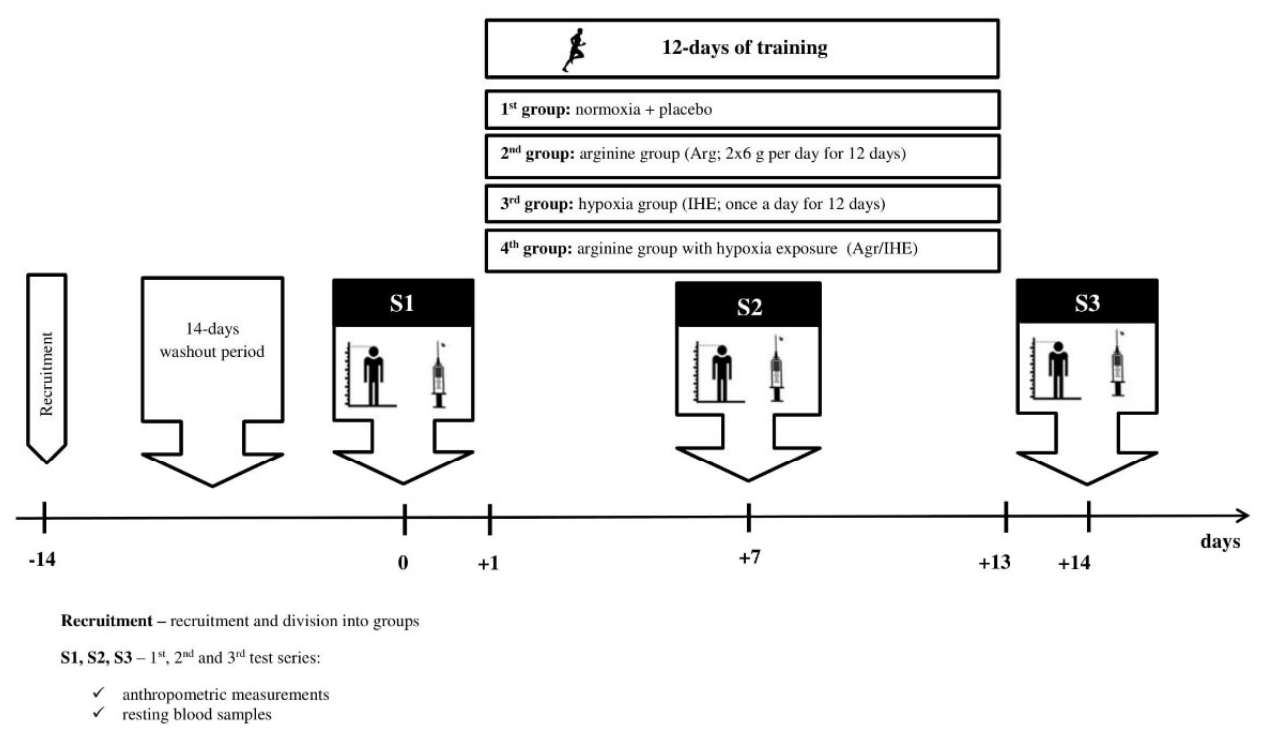

Figure 1. Illustration of the study design.

\subsection{Intermittent Hypoxic Exposure}

The passive 12-day intermittent hypoxic exposure (IHE) was conducted under medical supervision according to the procedure by Hinickson et al. [15] using the $\mathrm{GO}_{2}$ Altitude hypoxicator (Australia) at the Olympic Sports Centre (Figure 1). The hypoxicator was able to simulate the height of 2500 to $6500 \mathrm{~m}$ above sea level by regulating oxygen levels at $\mathrm{FiO}_{2}$ of $14-9 \%$ (fraction of inspired oxygen). Intermittent hypoxic exposure parameters were determined after the preliminary assessment of athlete's ability to adapt to hypoxic gas mixtures. The hypoxic test included the measurements of the time for the blood saturation to drop to $85 \%$ with $\mathrm{FiO}_{2}=12 \%$ (equivalent to $4500 \mathrm{~m}$ above sea level) and the time for the blood saturation to return to $95 \%$ in normoxia. Based on the hypoxic test results, the IHE protocol was determined for every athlete. IHE was applied once a day, at least $2 \mathrm{~h}$ after sports training. Each IHE session consisted of 6 doses of 3-8-min periods of hypoxia (at $\mathrm{FiO}_{2}$ of $14-12 \%$ ) interrupted by 3-5-min periods of normoxia, and repeated for 60-80 min. Hypoxic exposure started with two sessions with the oxygen concentration in the mask at $\mathrm{FiO}_{2}$ of $13.5 \%$ (equivalent to $\sim 3000 \mathrm{~m}$ above sea level) and then reduced the oxygen concentration to $\mathrm{FiO}_{2}$ of $12 \%$ (equivalent to $\sim 4500 \mathrm{~m}$ above sea level). The blood saturation $\left(\mathrm{SpO}_{2}\right)$ and heart rate (HR) were individually monitored during every IHE session. $\mathrm{SpO}_{2}$ oscillated from $90.8 \pm 2.4 \%$ on 1 st day to $91.4 \pm 5.6 \%$ whereas HR oscillated from $76.0 \pm 7.8 \mathrm{bpm}$ on 1 st day to $76.1 \pm 11.8 \mathrm{bpm}$ on in groups exposed to hypoxia.

\subsection{Body Composition}

Body mass (BM) and body composition: fat-free mass (FFM) and fat mass (FM) were estimated using Tanita Body Composition Analyser MC-418 (Japan) calibrated prior to each test session in accordance with the manufacturer's guidelines. Duplicate measures were taken with the participant in a standing position; the average value was used for the final analysis. The recurrence of measurement amounted to $98 \%$. The measurements were taken between 7.00 and 8.00 a.m. before blood sampling.

\subsection{Blood Sampling}

Blood samples were taken 3-fold (on the 1st, 7th and 14th days of the training camp) from the median cubital vein between 7.00 and 8.00 a.m. after an overnight sleep, using S-Monovette tubes (Sarstedt, Austria). Within $20 \mathrm{~min}$., they were centrifuged at $3000 \times \mathrm{g}$ and $+8^{\circ} \mathrm{C}$ for $10 \mathrm{~min}$. Aliquots of serum were stored at $-80^{\circ} \mathrm{C}$. All samples were analysed in duplicate or triplicate in a single assay to avoid inter-assay variability. The intra-assay coefficients of variation $(\mathrm{CV})$ for the used kits were $<5 \%$. 


\subsection{Skeletal Muscle Damage}

Serum total creatine kinase (CK) activity was used as a marker of sarcolemma disruption and was evaluated by using commercially available reagents and mobile spectrophotometer DP 310 Vario II (Germany) at a temperature of $20-25^{\circ} \mathrm{C}$. The CK activity has been measured immediately after serum collection for the consecutive days of the conditioning camp. Percentage of changes in CK activity (\%CK) was calculated by comparing the initial value on the 1st day with peak activity on the 7 th and the 14th days of the conditioning camp.

\subsection{Oxi-Inflammatory Mediators}

Serum nitric oxide (NO) and hydrogen peroxide $\left(\mathrm{H}_{2} \mathrm{O}_{2}\right)$ were measured by enzyme immunoassay and colorimetric methods using the Oxis Research kits (USA). $\mathrm{NO}$ and $\mathrm{H}_{2} \mathrm{O}_{2}$ detection limits were estimated at $0.5 \mu \mathrm{mol} / \mathrm{L}$ and $6.25 \mu \mathrm{mol} / \mathrm{L}$, respectively. C-reactive protein (CRP) concentration was determined using commercial kit from DRG International (USA) with the detection limit $0.001 \mathrm{mg} / \mathrm{L}$.

\subsection{Growth Factors}

Serum hepatocyte growth factor (HGF), insulin-like growth factor (IGF-1), muscle isoform of platelet-derived growth factor $\left(\mathrm{PDGF}^{\mathrm{BB}}\right)$, vascular endothelial growth factor (VEGF) and brain-derived neutrophic factor (BDNF) were evaluated by R\&D Systems ELISA kits (USA). Detection limits were estimated at $40 \mathrm{pg} / \mathrm{mL}, 0.026 \mathrm{ng} / \mathrm{mL}, 15 \mathrm{pg} / \mathrm{mL}, 9 \mathrm{pg} / \mathrm{mL}$ and $20 \mathrm{pg} / \mathrm{mL}$, respectively.

\subsection{Lipoprotein-Lipid Profile}

Total cholesterol (TC), high-density lipoproteins (HDL) and low-density lipoproteins (LDL) as well as triglycerides (TG) were determined by professional laboratory company Diagnostyka (Poland, ISO 15189). The non-HDL cholesterol was calculated by subtracting HDL from total cholesterol concentration.

\subsection{Haematological Variables}

The haematological markers (HB, RBC, RET, HTC, MCV, MCH, MCHC, RDW) and white blood cells (WBC) were determined by Diagnostyka (Poland, ISO 15189). Erythropoietin (EPO) was determined by enzyme immunoassay methods using the R\&D Systems kits (USA). The detection limit for EPO was estimated at $0.6 \mathrm{mlU} / \mathrm{mL}$.

\subsection{Statistical Analysis}

Statistical analyses were performed using the R system, version 3.6.1 [https://www.r-project.org]. The significant differences in mean values between the groups (Control, Arg, IHE and Arg/IHE) were assessed mainly by the one-way ANOVA and the Tukey's post hoc tests. The assumptions for the use of parametric or non-parametric tests were checked using the Shapiro-Wilk and the Levene tests to evaluate the normality of the distributions and the homogeneity of variances, respectively. The significant differences for $\mathrm{NO}$ and $\mathrm{H}_{2} \mathrm{O}_{2}$ were assessed first by the one-way MANOVA. A statistically significant one-way MANOVA can be followed up by univariate one-way ANOVA examining, separately, each dependent variable. Moreover, the appropriate multivariate tests for checking assumptions were used (i.e., multivariate normality and homogeneity of variance-covariance matrices). In the case of ANOVA, if the normality and homogeneity assumptions were violated, the Kruskal-Wallis non-parametric test was used. The comparisons of repeated measurements (1st vs. 7th and 1st vs. 14th days of the camp) were assessed by the t-Student test or the Wilcoxon signed-rank test depending on compliance with the normality assumption. Additionally, eta-squared $\left(\eta^{2}\right)$ was used as a measure of effect size, which is indicated as having no effect if $0 \leq \eta^{2}<0.05$, a minimum effect if $0.05 \leq \eta^{2}<0.26$, a moderate effect if $0.026 \leq \eta^{2}<0.64$ and a strong effect if $\eta^{2} \geq 0.64$ [16]. Pearson's correlation coefficients 
were calculated to describe the relationships between $\mathrm{CK}, \mathrm{NO}, \mathrm{H}_{2} \mathrm{O}_{2}$ and growth factors. Statistical significance was set at $p<0.05$.

\section{Results}

\subsection{Skeletal Muscle Damage}

CK activity reached 2-fold increase on the 7th day and 14th days of the conditioning camp in controls and Arg whereby \%CK did not significantly differ between groups. The hypoxic exposure increased \%CK activity significantly by $357 \pm 78 \%$ on the 7 th day and by $684 \pm 117 \%$ on the 14 th day in IHE and by $263 \pm 159 \%$ on the 7th day and by $586 \pm 270 \%$ on the 14th day compared to the 1 st day of the training camp in Arg/IHE group. However, CK did not reach the values $>3000 \mathrm{IU} / \mathrm{L}$, which were observed following very intensive training in our previous study [17]. The total CK activity highly correlated with $\mathrm{NO}(\mathrm{r}=0.720, P<0.001)$ and $\mathrm{H} 2 \mathrm{O} 2(\mathrm{r}=0.646, P<0.001)$. This indicates that hypoxia-induced generation of reactive oxygen and nitrogen species increases skeletal muscles damage.

\subsection{Oxi-Inflammatory Mediators}

The results are presented in Table 2. The changes in $\mathrm{NO}$ and $\mathrm{H}_{2} \mathrm{O}_{2}$ concentrations proceeded simultaneously and reached the highest values on the last day of the training camp (Figures 2-4). The hypoxic exposure resulted in above 2-fold increase in $\mathrm{NO}$ and $\mathrm{H}_{2} \mathrm{O}_{2}$ concentration on the 7th day of the training camp, and during the following days $\mathrm{NO}$ and $\mathrm{H}_{2} \mathrm{O}_{2}$ remained at a high level in IHE and $\mathrm{Arg} / \mathrm{IHE}$ groups. The $\mathrm{NO} / \mathrm{H}_{2} \mathrm{O}_{2}$ ratio decreased in IHE and $\mathrm{Arg} / \mathrm{IHE}$ compared to control group, which indicates a more significant influence of intermittent hypoxia on $\mathrm{H}_{2} \mathrm{O}_{2}$ than on $\mathrm{NO}$ generation. The value $\eta^{2}$ showed a strong effect of arginine and/or IHE on $\mathrm{NO}$ and $\mathrm{H}_{2} \mathrm{O}_{2}$ concentrations on the 7th and 14th days of observation, i.e., the time of arginine and/or IHE administration determined the extent of changes in both molecules. CRP concentration significantly increased in response to hypoxic exposure in IHE and Arg/IHE compared with control on the 7th day, but it remained on the level $<5 \mathrm{mg} / \mathrm{L}$. Since the increased CRP level did not exceed the reference values, we concluded that hypoxic exposure applied in our study did not adversely affect the athletes' inflammatory status.

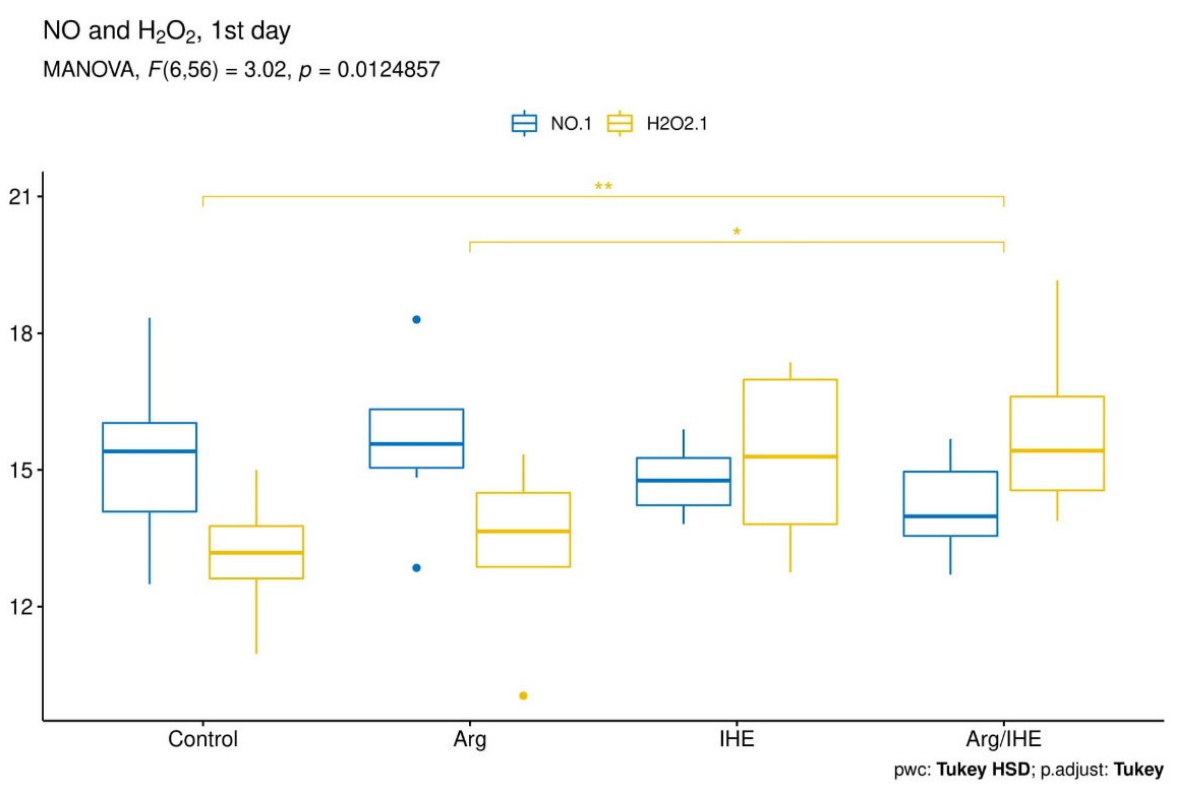

Figure 2. Visualisation of the MANOVA statistical analysis of changes in nitric oxide (NO) and hydrogen peroxide $\left(\mathrm{H}_{2} \mathrm{O}_{2}\right)$ levels on the 1st day of the training camp for the following groups: control, arginine (Arg), hypoxic exposure (IHE) and arginine with hypoxic exposure (Arg/IHE). Results of the Tukey HSD post-hoc comparisons are coded as follows: ${ }^{*} p<0.05,{ }^{* *} p<0.01$. The homogeneity of covariances and multivariate normality assumptions are met. 
Table 2. The levels of oxi-inflammatory mediators.

\begin{tabular}{|c|c|c|c|c|c|c|c|c|c|c|c|}
\hline & \multicolumn{3}{|c|}{ 1st Day of Camp } & \multicolumn{3}{|c|}{ 7th Day of Camp } & \multicolumn{3}{|c|}{ 14th Day of Camp } & \multirow[b]{2}{*}{$\begin{array}{l}\text { 1st Day vs. } \\
\text { 7th Day }\end{array}$} & \multirow[b]{2}{*}{$\begin{array}{c}\text { 1st Day vs } \\
\text { 14th Day }\end{array}$} \\
\hline & Mean \pm SD & $\begin{array}{l}\text { Control vs. } \\
\text { Arg, IHE or } \\
\text { Arg/IHE }\end{array}$ & $\eta^{2}$ & Mean \pm SD & $\begin{array}{l}\text { Control vs. } \\
\text { Arg, IHE or } \\
\text { Arg/IHE }\end{array}$ & $\eta^{2}$ & Mean \pm SD & $\begin{array}{l}\text { Control vs. } \\
\text { Arg, IHE or } \\
\text { Arg/IHE }\end{array}$ & $\eta^{2}$ & & \\
\hline \multicolumn{12}{|c|}{$\mathrm{NO}[\mu \mathrm{mol} / \mathrm{L}]$} \\
\hline Control & $15.37 \pm 1.83$ & - & \multirow{4}{*}{0.166} & $15.36 \pm 1.26$ & - & \multirow{4}{*}{0.569} & $17.33 \pm 0.99$ & - & \multirow{4}{*}{0.701} & 0.995 & $<0.05$ \\
\hline Arg & $15.64 \pm 1.66$ & 0.98 & & $17.67 \pm 1.19$ & $<0.01$ & & $18.97 \pm 1.67$ & 0.326 & & $<0.01$ & $<0.01$ \\
\hline $\mathrm{IHE}$ & $14.78 \pm 0.79$ & 0.856 & & $18.71 \pm 0.73$ & $<0.001$ & & $22.26 \pm 0.95$ & $<0.001$ & & $<0.05$ & $<0.001$ \\
\hline Arg/IHE & $14.12 \pm 0.95$ & 0.251 & & $18.67 \pm 1.78$ & $<0.001$ & & $23.93 \pm 3.02$ & $<0.001$ & & $<0.001$ & $<0.01$ \\
\hline \multicolumn{12}{|c|}{$\mathbf{H}_{2} \mathbf{O}_{2}[\mu \mathrm{mol} / \mathrm{L}]$} \\
\hline Control & $13.16 \pm 1.13$ & - & \multirow{4}{*}{0.382} & $16.67 \pm 2.00$ & - & \multirow{4}{*}{0.92} & $17.87 \pm 3.15$ & - & \multirow{4}{*}{0.678} & $<0.001$ & $<0.01$ \\
\hline Arg & $13.39 \pm 1.76$ & 0.992 & & $13.99 \pm 3.66$ & 0.46 & & $17.34 \pm 4.45$ & 0.994 & & 0.748 & $<0.05$ \\
\hline $\mathrm{IHE}$ & $15.26 \pm 1.99$ & 0.098 & & $40.36 \pm 4.64$ & $<0.001$ & & $30.93 \pm 4.81$ & $<0.001$ & & $<0.001$ & $<0.001$ \\
\hline Arg/IHE & $15.97 \pm 1.91$ & $<0.01$ & & $39.47 \pm 4.36$ & $<0.001$ & & $27.41 \pm 4.63$ & $<0.001$ & & $<0.001$ & $<0.001$ \\
\hline \multicolumn{12}{|c|}{$\begin{array}{c}\mathrm{NO} / \mathrm{H}_{2} \mathrm{O}_{2} \text { ratio } \\
{[\mu \mathrm{mol} / \mathrm{L}]}\end{array}$} \\
\hline Control & $1.17 \pm 0.10$ & - & \multirow{4}{*}{0.456} & $0.93 \pm 0.13$ & - & & $0.99 \pm 0.15$ & - & \multirow{4}{*}{0.386} & $<0.01$ & $<0.05$ \\
\hline Arg & $1.19 \pm 0.23$ & 0.986 & & $1.35 \pm 0.42$ & $<0.01$ & & $1.13 \pm 0.19$ & 0.383 & & 0.505 & 0.675 \\
\hline IHE & $0.98 \pm 0.13$ & 0.095 & & $0.47 \pm 0.05$ & $<0.01$ & & $0.74 \pm 0.15$ & $<0.05$ & & $<0.001$ & $<0.05$ \\
\hline Arg/IHE & $0.90 \pm 0.12$ & $<0.01$ & & $0.51 \pm 0.10$ & $<0.01$ & & $0.90 \pm 0.20$ & 0.615 & & $<0.001$ & 0.974 \\
\hline \multicolumn{12}{|c|}{ CRP $[\mathrm{mg} / \mathrm{L}]$} \\
\hline Control & $1.57 \pm 0.53$ & - & \multirow{4}{*}{0.024} & $2.02 \pm 0.35$ & - & \multirow{4}{*}{0.552} & $2.29 \pm 0.48$ & - & & $<0.05$ & $<0.01$ \\
\hline Arg & $1.62 \pm 0.49$ & 0.997 & & $1.99 \pm 0.55$ & 0.999 & & $2.14 \pm 0.41$ & 0.917 & \multirow{3}{*}{0.115} & 0.182 & 0.097 \\
\hline IHE & $1.45 \pm 0.15$ & 0.968 & & $2.69 \pm 0.41$ & $<0.05$ & & $2.46 \pm 0.28$ & 0.913 & & $<0.001$ & $<0.001$ \\
\hline Arg/IHE & $1.66 \pm 0.57$ & 0.977 & & $3.09 \pm 0.52$ & $<0.001$ & & $2.58 \pm 0.63$ & 0.589 & & $<0.001$ & $<0.01$ \\
\hline
\end{tabular}

Abbreviations: NO, nitric oxide; $\mathrm{H} 2 \mathrm{O} 2$, hydrogen peroxide; CRP, C-reactive protein; $\eta^{2}$ is a measure of effect size. Data in columns whose names begin with "Control" show the $p$-values of the Tukey's post-hoc tests of the univariate one-way ANOVA examining, separately, each dependent variable. The last two columns show the $p$-values of the t-Student test or the Wilcoxon nonparametric test (if the normality assumption is violated) 


\section{$\mathrm{NO}$ and $\mathrm{H}_{2} \mathrm{O}_{2}$, 7th day}

MANOVA, $F(6,56)=15.79, p=1.620291 \mathrm{e}-10$

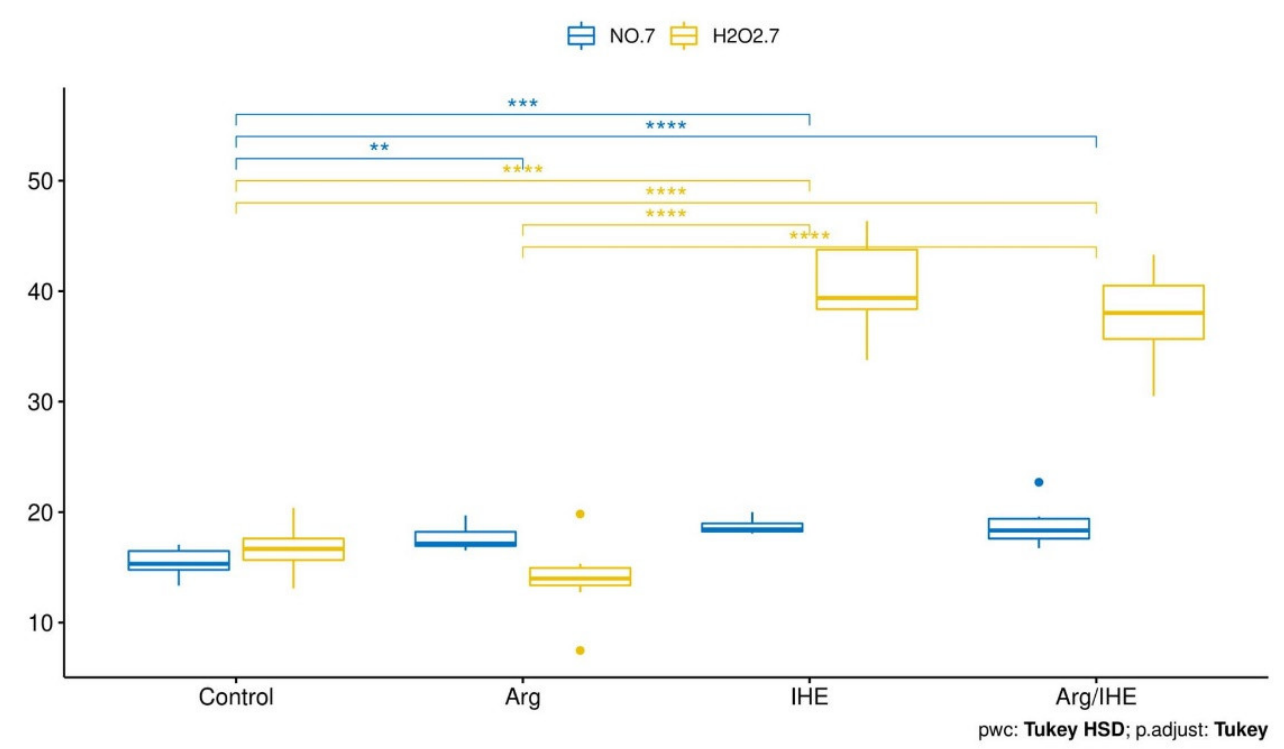

Figure 3. Visualisation of the MANOVA statistical analysis of changes in nitric oxide (NO) and hydrogen peroxide $\left(\mathrm{H}_{2} \mathrm{O}_{2}\right)$ levels on the 7th day of the training camp for the following groups: control, arginine (Arg), hypoxic exposure (IHE) and arginine with hypoxic exposure (Arg/IHE). Results of the Tukey HSD post-hoc comparisons are coded as follows: ${ }^{* *} p<0.01,{ }^{* * *} p<0.001$, ${ }^{* * * *} p<0.0001$. The homogeneity of covariances and multivariate normality assumptions are met.

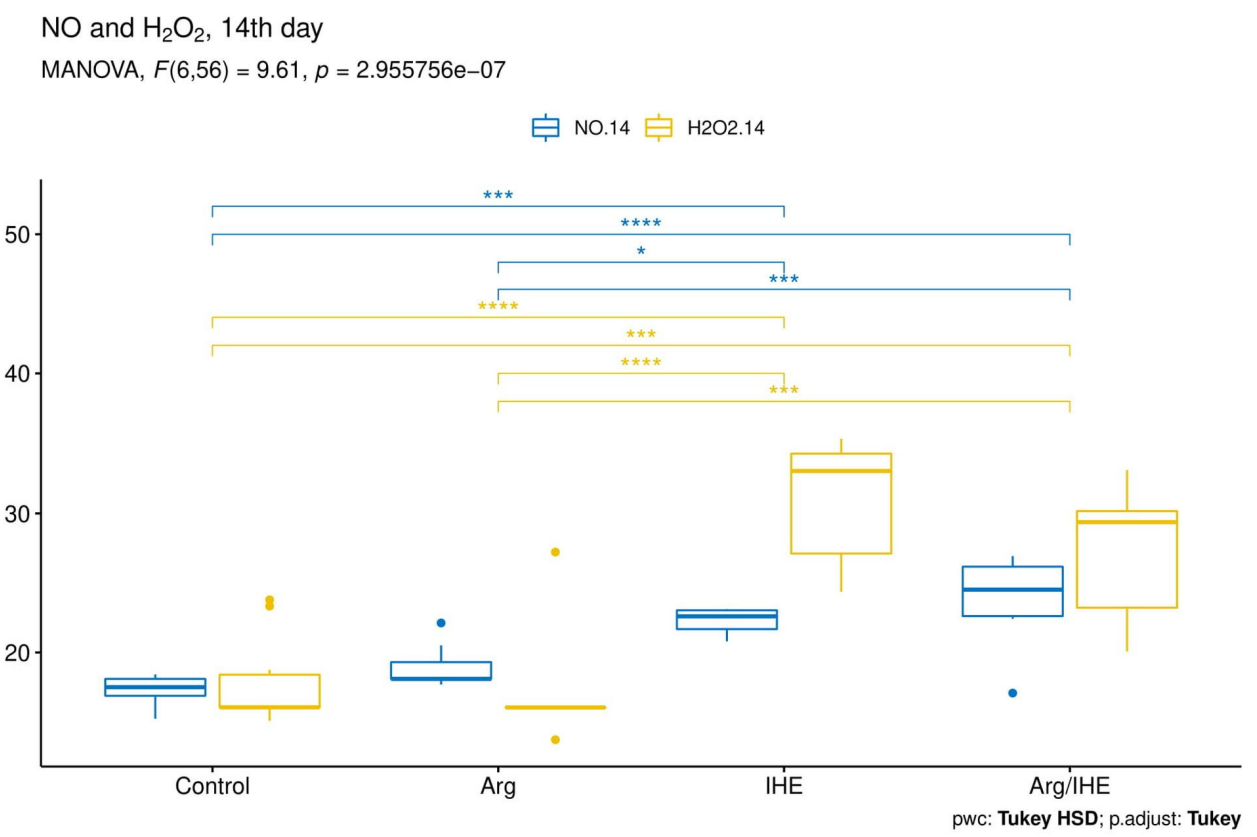

Figure 4. Visualisation of the MANOVA statistical analysis of changes in nitric oxide (NO) and hydrogen peroxide $\left(\mathrm{H}_{2} \mathrm{O}_{2}\right)$ levels on the 14th day of the training camp for the following groups: control, arginine (Arg), hypoxic exposure (IHE) and arginine with hypoxic exposure (Arg/IHE). Results of the Tukey HSD post-hoc comparisons are coded as follows: ${ }^{*} p<0.05,{ }^{* * *} p<0.001,{ }^{* * * *} p<0.0001$. The homogeneity of covariances and multivariate normality assumptions are met. 


\subsection{Growth Factors}

The results are presented in Table 3. The changes in circulating growth factors levels proceeded differently following sports training and arginine intake, and they were dependent on skeletal muscle damage. The levels of PDGFBB, BDNF and VEGF increased on the 7th day; HGF level rose on the 14th day whereas IGF-1 decreased in controls and Arg. Hypoxic exposure elevated growth factors except for BDNF, which significantly decreased on the 7th and 14th days compared to the initial level and control group. $\mathrm{NO}$ and $\mathrm{H}_{2} \mathrm{O}_{2}$ generation significantly modulated the release of growth factors into the circulation. The strongest association was observed for NO, $\mathrm{H}_{2} \mathrm{O}_{2}$ and IGF-1 (Table 4). The value $\eta^{2}$ indicated a strong effect of arginine and/or IHE administration on growth factors concentrations, particularly on the 14th day of observation. This means that the duration of use of arginine and hypoxia determine the extent of the changes in growth factors, similarly to nitric oxide.

\subsection{Haematological Variables}

The results are presented in Table 5. No changes in $\mathrm{HB}$ concentration were observed whereas contrasting changes were identified in other haematological markers, i.e., RBC and HTC levels decreased while RET concentration increased in all subjects during the 14-day observation. The serum EPO level rose significantly in all subjects on the 7th and 14th days. However, what hypoxia exposure, alone or with arginine intake, exerted the greatest influence on was EPO concentration. EPO level highly correlated with $\mathrm{NO}(\mathrm{r}=0.624, p<0.001)$ and $\mathrm{H}_{2} \mathrm{O}_{2}(\mathrm{r}=0.600, p<0.001)$, which indicates their substantial share in erythropoietin synthesis. A moderate effect of arginine and/or IHE administration on EPO concentration was also proven by the value $\eta^{2}$. WBC count increased on the 14th day of the training camp in all subjects but fell within the normal range (from $4.0 \times 10^{3} / \mu \mathrm{L}$ to $10.0 \times 10^{3} / \mu \mathrm{L}$ ). Therefore, we concluded that arginine intake and/or hypoxic exposure applied in our study did not adversely affect the athletes' immune function.

\subsection{Lipoprotein-Lipid Profile}

The results are presented in Table 6. TG, TC, LDL and HDL concentrations were found to be at similar levels in all subjects. On the 1st day of observation, high levels of TC and LDL were detected in $40 \%$ ( $>200 \mathrm{mg} / \mathrm{dL}$ ) and $31 \%$ (>130 mg/dL) of the subjects, respectively. Finally, non-HDL exceeded the level of $145 \mathrm{mg} / \mathrm{dL}$ in $40 \%$ of the athletes. A decreasing trend of all the elements of lipid profile was observed on 14th day in Arg and IHE when compared to control group. Interestingly, hypoxic exposure induced approx. $20 \%$ decrease in non-HDL on the 7th and 14th days compared to the 1st day of sports training. The value $\eta^{2}$ showed a moderate impact of arginine and/or IHE administration on non-HDL concentration, especially on the 14th day of the observation. 
Table 3. The levels of tissue regeneration mediators.

\begin{tabular}{|c|c|c|c|c|c|c|c|c|c|c|c|}
\hline & \multicolumn{3}{|c|}{ 1st Day of Camp } & \multicolumn{3}{|c|}{ 7th Day of Camp } & \multicolumn{3}{|c|}{ 14th Day of Camp } & \multirow[b]{2}{*}{$\begin{array}{l}\text { 1st Day vs. } \\
\text { 7th Day }\end{array}$} & \multirow[b]{2}{*}{$\begin{array}{l}\text { 1st Day vs. } \\
\text { 14th Day }\end{array}$} \\
\hline & Mean \pm SD & $\begin{array}{c}\text { Control vs. } \\
\text { Arg, IHE or } \\
\text { Arg/IHE }\end{array}$ & $\eta^{2}$ & Mean \pm SD & $\begin{array}{c}\text { Control vs. } \\
\text { Arg, IHE or } \\
\text { Arg/IHE }\end{array}$ & $\eta^{2}$ & Mean \pm SD & $\begin{array}{c}\text { Control vs. } \\
\text { Arg, IHE or } \\
\text { Arg/IHE }\end{array}$ & $\eta^{2}$ & & \\
\hline \multicolumn{12}{|c|}{ HGF [pg/mL] } \\
\hline Control & $587 \pm 73$ & - & \multirow{4}{*}{0.237} & $534 \pm 77$ & - & \multirow{4}{*}{0.467} & $602 \pm 68$ & - & \multirow{4}{*}{0.653} & $<0.01$ & 0.625 \\
\hline Arg & $620 \pm 60$ & 0.687 & & $568 \pm 89$ & 0.827 & & $770 \pm 69$ & $<0.001$ & & $<0.05$ & $<0.01$ \\
\hline IHE & $623 \pm 61$ & 0.666 & & $546 \pm 95$ & 0.992 & & $792 \pm 49$ & $<0.001$ & & 0.094 & $<0.05$ \\
\hline $\mathrm{Arg} / \mathrm{IHE}$ & $544 \pm 42$ & 0.425 & & $708 \pm 72$ & $<0.001$ & & $789 \pm 71$ & $<0.001$ & & $<0.001$ & $<0.001$ \\
\hline \multicolumn{12}{|c|}{ IGF-1 [ng/mL] } \\
\hline Control & $120 \pm 41$ & - & \multirow{4}{*}{0.19} & $116 \pm 22$ & - & \multirow{4}{*}{0.867} & $100 \pm 15$ & - & \multirow{4}{*}{0.911} & 0.16 & 0.084 \\
\hline Arg & $126 \pm 23$ & 0.982 & & $103 \pm 19$ & 0.834 & & $98 \pm 12$ & 0.998 & & 0.073 & $<0.01$ \\
\hline IHE & $149 \pm 11$ & 0.231 & & $248 \pm 26$ & $<0.001$ & & $206 \pm 29$ & $<0.001$ & & $<0.001$ & $<0.01$ \\
\hline Arg/IHE & $148 \pm 26$ & 0.186 & & $280 \pm 51$ & $<0.001$ & & $293 \pm 43$ & $<0.001$ & & $<0.001$ & $<0.001$ \\
\hline \multicolumn{12}{|c|}{ PDGFBB [pg/mL] } \\
\hline Control & $2281 \pm 513$ & - & \multirow{4}{*}{0.084} & $2646 \pm 289$ & - & \multirow{4}{*}{0.381} & $2068 \pm 368$ & - & \multirow{4}{*}{0.706} & 0.074 & 0.063 \\
\hline Arg & $2327 \pm 418$ & 0.995 & & $2836 \pm 293$ & 0.806 & & $1980 \pm 161$ & 0.927 & & 0.062 & 0.088 \\
\hline IHE & $2582 \pm 231$ & 0.456 & & $2762 \pm 160$ & 0.953 & & $3133 \pm 263$ & $<0.001$ & & 0.15 & $<0.01$ \\
\hline Arg/IHE & $2307 \pm 266$ & 0.999 & & $3418 \pm 686$ & $<0.01$ & & $2478 \pm 274$ & $<0.05$ & & $<0.01$ & 0.226 \\
\hline \multicolumn{12}{|c|}{ BDNF $[\mathrm{pg} / \mathrm{mL}]$} \\
\hline Control & $23,447 \pm 3237$ & - & \multirow{4}{*}{0.067} & $27,486 \pm 1974$ & - & \multirow{4}{*}{0.781} & $27,426 \pm 2452$ & - & \multirow{4}{*}{0.789} & $<0.05$ & $<0.01$ \\
\hline Arg & $23,922 \pm 3040$ & 0.987 & & $29,567 \pm 2651$ & 0.301 & & $26,626 \pm 1250$ & 0.88 & & $<0.05$ & 0.073 \\
\hline IHE & $22,402 \pm 3184$ & 0.899 & & $18,817 \pm 1118$ & $<0.001$ & & $18,154 \pm 1377$ & $<0.001$ & & 0.059 & 0.053 \\
\hline Arg/IHE & $22,120 \pm 2177$ & 0.756 & & $21,218 \pm 3025$ & $<0.001$ & & $19,952 \pm 2791$ & $<0.001$ & & 0.198 & $<0.05$ \\
\hline \multicolumn{12}{|c|}{ VEGF [pg/mL] } \\
\hline Control & $341 \pm 68$ & - & \multirow{4}{*}{0.03} & $405 \pm 54$ & - & \multirow{4}{*}{0.112} & $234 \pm 65$ & - & \multirow{4}{*}{0.782} & 0.085 & $<0.001$ \\
\hline Arg & $361 \pm 64$ & 0.861 & & $408 \pm 63$ & 0.958 & & $238 \pm 77$ & 0.999 & & 0.154 & $<0.05$ \\
\hline IHE & $330 \pm 44$ & 0.999 & & $406 \pm 46$ & 0.974 & & $389 \pm 45$ & $<0.001$ & & $<0.05$ & 0.135 \\
\hline Arg/IHE & $344 \pm 78$ & 0.991 & & $452 \pm 97$ & 0.284 & & $495 \pm 64$ & $<0.001$ & & 0.054 & $<0.01$ \\
\hline
\end{tabular}

Abbreviations: Arg, arginine supplementation; IHE, intermittent hypoxic exposure; Arg/IHE, arginine supplementation and intermittent hypoxic exposure; HGF, hepatocyte growth factor; IGF-1, insulin-like growth factor $1 \beta$; PDGF ${ }^{B B}$, platelet-derived growth factor; BDNF, brain-derived neurotrophic factor; VEGF, vascular endothelial growth factor; $\eta^{2}$ is a measure of effect size. Data in columns whose names begin with "Control" show the $p$-values of the Tukey's post-hoc tests of the univariate one-way ANOVA examining, separately, each dependent variable. The last two columns show the $p$-values of the t-Student test or the Wilcoxon nonparametric test (if the normality assumption is violated). 
Table 4. Relationships (Pearson's correlation coefficients) between oxi-inflammatory mediators $\mathrm{NO}_{\text {and }} \mathrm{H}_{2} \mathrm{O}_{2}$, and growth factors HGF, IGF-1, PDGF ${ }^{\mathrm{BB}}$, BDNF and VEGF.

\begin{tabular}{cccccc}
\hline & HGF $[\mathrm{pg} / \mathrm{mL}]$ & IGF-1 [ng/mL] & PDGF $^{\text {BB }}[\mathrm{pg} / \mathrm{mL}]$ & BDNF $[\mathrm{pg} / \mathrm{mL}]$ & VEGF [pg/mL] \\
\hline \multirow{2}{*}{$\mathrm{NO}[\mu \mathrm{mol} / \mathrm{L}]$} & 0.662 & 0.554 & 0.160 & -0.286 & 0.274 \\
& $<0.001$ & $<0.001$ & $>0.05$ & $<0.01$ & $<0.01$ \\
\hline \multirow{2}{*}{$\mathbf{H}_{\mathbf{2}} \mathbf{O}_{\mathbf{2}}[\mu \mathrm{mol} / \mathrm{L}]$} & 0.321 & 0.780 & 0.479 & -0.525 & 0.368 \\
& $<0.01$ & $<0.001$ & $<0.001$ & $<0.001$ & $<0.001$ \\
\hline
\end{tabular}

Table 5. Haematological markers and immune cells count.

\begin{tabular}{|c|c|c|c|c|c|c|c|c|c|c|c|}
\hline & \multicolumn{3}{|c|}{ 1st Day of Camp } & \multicolumn{3}{|c|}{ 7th Day of Camp } & \multicolumn{3}{|c|}{ 14th Day of Camp } & \multirow[b]{2}{*}{$\begin{array}{l}\text { 1st Day vs. } \\
\text { 7th Day }\end{array}$} & \multirow[b]{2}{*}{$\begin{array}{l}\text { 1st day vs. } \\
\text { 14th day }\end{array}$} \\
\hline & Mean \pm SD & $\begin{array}{l}\text { Control vs. } \\
\text { Arg, IHE or } \\
\text { Arg/IHE }\end{array}$ & $\eta^{2}$ & Mean \pm SD & $\begin{array}{l}\text { Control vs. } \\
\text { Arg, IHE or } \\
\text { Arg/IHE }\end{array}$ & $\eta^{2}$ & Mean \pm SD & $\begin{array}{l}\text { Control vs. } \\
\text { Arg, IHE or } \\
\text { Arg/IHE }\end{array}$ & $\eta^{2}$ & & \\
\hline \multicolumn{12}{|l|}{$\mathrm{HB}[\mathrm{g} / \mathrm{dL}]$} \\
\hline Control & $15.3 \pm 0.8$ & - & \multirow{4}{*}{0.043} & $15.2 \pm 0.7$ & - & \multirow{4}{*}{0.165} & $15.5 \pm 0.2$ & - & \multirow{4}{*}{0.462} & 0.918 & 0.335 \\
\hline Arg & $14.9 \pm 0.8$ & 0.757 & & $14.8 \pm 0.5$ & 0.617 & & $14.6 \pm 0.3$ & $<0.01$ & & 0.271 & 0.306 \\
\hline IHE & $15.1 \pm 0.8$ & 0.961 & & $14.4 \pm 1.0$ & 0.137 & & $14.3 \pm 0.6$ & $<0.01$ & & 0.071 & 0.218 \\
\hline Arg/IHE & $15.3 \pm 0.7$ & 1 & & $15.1 \pm 0.7$ & 0.947 & & $15.2 \pm 0.8$ & 0.517 & & 0.16 & 0.851 \\
\hline \multicolumn{12}{|c|}{$\mathbf{R B C}\left[\mathrm{mln} / \mathrm{mm}^{3}\right]$} \\
\hline Control & $5.4 \pm 0.3$ & - & \multirow{4}{*}{0.189} & $5.4 \pm 0.2$ & - & \multirow{4}{*}{0.392} & $5.1 \pm 0.2$ & - & \multirow{4}{*}{0.736} & 0.411 & $<0.05$ \\
\hline Arg & $5.3 \pm 0.5$ & 0.781 & & $5.2 \pm 0.3$ & 0.286 & & $4.6 \pm 0.1$ & $<0.001$ & & 0.636 & $<0.05$ \\
\hline $\mathrm{IHE}$ & $5.2 \pm 0.4$ & 0.852 & & $5.0 \pm 0.5$ & $<0.05$ & & $4.7 \pm 0.3$ & $<0.01$ & & 0.055 & $<0.05$ \\
\hline Arg/IHE & $5.0 \pm 0.2$ & 0.076 & & $4.9 \pm 0.2$ & $<0.01$ & & $5.5 \pm 0.3$ & $<0.05$ & & 0.065 & $<0.01$ \\
\hline \multicolumn{12}{|l|}{ RET [\%o] } \\
\hline Control & $4.1 \pm 1.1$ & - & \multirow{4}{*}{0.222} & $5.2 \pm 1.2$ & - & \multirow{4}{*}{0.459} & $7.1 \pm 2.2$ & - & \multirow{4}{*}{0.505} & $<0.05$ & $<0.01$ \\
\hline Arg & $4.1 \pm 1.2$ & 1 & & $5.0 \pm 1.4$ & 0.994 & & $10.1 \pm 1.8$ & $<0.05$ & & 0.2 & $<0.001$ \\
\hline $\mathrm{IHE}$ & $3.0 \pm 0.6$ & 0.139 & & $8.7 \pm 2.5$ & $<0.001$ & & $12.0 \pm 1.4$ & $<0.001$ & & $<0.01$ & $<0.001$ \\
\hline Arg/IHE & $3.3 \pm 0.7$ & 0.295 & & $6.4 \pm 1.1$ & 0.319 & & $9.3 \pm 1.7$ & 0.071 & & $<0.001$ & $<0.01$ \\
\hline
\end{tabular}


Table 5. Cont.

\begin{tabular}{|c|c|c|c|c|c|c|c|c|c|c|c|}
\hline & \multicolumn{3}{|c|}{ 1st Day of Camp } & \multicolumn{3}{|c|}{ 7th Day of Camp } & \multicolumn{3}{|c|}{ 14th Day of Camp } & \multirow[b]{2}{*}{$\begin{array}{l}\text { 1st Day vs. } \\
\text { 7th Day }\end{array}$} & \multirow[b]{2}{*}{$\begin{array}{c}\text { 1st day vs } \\
14 \text { th day }\end{array}$} \\
\hline & Mean \pm SD & $\begin{array}{l}\text { Control vs. } \\
\text { Arg, IHE or } \\
\text { Arg/IHE }\end{array}$ & $\eta^{2}$ & Mean \pm SD & $\begin{array}{l}\text { Control vs. } \\
\text { Arg, IHE or } \\
\text { Arg/IHE }\end{array}$ & $\eta^{2}$ & Mean \pm SD & $\begin{array}{l}\text { Control vs. } \\
\text { Arg, IHE or } \\
\text { Arg/IHE }\end{array}$ & $\eta^{2}$ & & \\
\hline \multicolumn{12}{|l|}{ HCT [\%] } \\
\hline Control & $48.1 \pm 3.0$ & - & \multirow{4}{*}{0.4} & $48.2 \pm 2.8$ & - & \multirow{4}{*}{0.45} & $45.8 \pm 1.5$ & - & \multirow{4}{*}{0.403} & 0.825 & $<0.05$ \\
\hline Arg & $47.9 \pm 3.0$ & 0.996 & & $47.2 \pm 1.8$ & 0.878 & & $43.0 \pm 1.2$ & $<0.01$ & & 0.444 & $<0.01$ \\
\hline IHE & $45.7 \pm 1.1$ & 0.221 & & $45.1 \pm 2.4$ & 0.164 & & $44.2 \pm 2.4$ & 0.176 & & 0.598 & 0.096 \\
\hline Arg/IHE & $43.8 \pm 1.7$ & $<0.01$ & & $42.3 \pm 3.7$ & $<0.001$ & & $45.8 \pm 1.0$ & 1 & & 0.41 & $<0.05$ \\
\hline \multicolumn{12}{|l|}{ MCV [fL] } \\
\hline Control & $89.3 \pm 3.9$ & - & \multirow{4}{*}{0.316} & $89.9 \pm 3.1$ & - & \multirow{4}{*}{0.427} & $89.8 \pm 2.0$ & - & \multirow{4}{*}{0.732} & 0.43 & 0.626 \\
\hline Arg & $92.1 \pm 3.0$ & 0.35 & & $91.8 \pm 2.8$ & 0.559 & & $93.5 \pm 0.3$ & $<0.05$ & & 0.647 & 0.278 \\
\hline IHE & $85.5 \pm 3.4$ & 0.163 & & $84.8 \pm 2.4$ & $<0.05$ & & $83.8 \pm 1.9$ & $<0.001$ & & 0.328 & 0.067 \\
\hline Arg/IHE & $88.0 \pm 3.2$ & 0.842 & & $87.8 \pm 3.1$ & 0.406 & & $85.0 \pm 3.5$ & $<0.001$ & & 0.681 & $<0.05$ \\
\hline \multicolumn{12}{|c|}{$\mathbf{M C H}[\mathrm{pg} / \mathrm{RBC}]$} \\
\hline Control & $28.4 \pm 1.0$ & - & \multirow{4}{*}{0.393} & $28.5 \pm 1.5$ & - & \multirow{4}{*}{0.311} & $30.5 \pm 0.9$ & - & \multirow{4}{*}{0.643} & 1 & $<0.001$ \\
\hline Arg & $28.7 \pm 1.5$ & 0.963 & & $28.6 \pm 0.9$ & 1 & & $32.0 \pm 0.6$ & $<0.05$ & & 1 & $<0.001$ \\
\hline IHE & $28.8 \pm 1.4$ & 0.934 & & $29.7 \pm 1.9$ & 0.377 & & $28.5 \pm 1.0$ & $<0.01$ & & 0.079 & 0.451 \\
\hline Arg/IHE & $30.7 \pm 1.2$ & $<0.01$ & & $30.6 \pm 1.1$ & $<0.05$ & & $28.6 \pm 1.5$ & $<0.01$ & & 0.681 & $<0.05$ \\
\hline \multicolumn{12}{|c|}{ MCHC $[\mathrm{g} / \mathrm{dL}]$} \\
\hline Control & $31.7 \pm 0.9$ & - & \multirow{4}{*}{0.826} & $31.7 \pm 1.1$ & - & \multirow{4}{*}{0.863} & $33.7 \pm 0.4$ & - & \multirow{4}{*}{0.158} & 0.968 & $<0.01$ \\
\hline Arg & $31.0 \pm 0.6$ & 0.241 & & $31.2 \pm 0.3$ & 0.522 & & $34.2 \pm 0.3$ & 0.221 & & 0.359 & $<0.05$ \\
\hline $\mathrm{IHE}$ & $33.5 \pm 0.2$ & $<0.001$ & & $35.1 \pm 0.9$ & $<0.001$ & & $33.7 \pm 0.6$ & 1 & & $<0.001$ & 0.336 \\
\hline Arg/IHE & $34.8 \pm 0.8$ & $<0.001$ & & $34.9 \pm 0.3$ & $<0.001$ & & $33.8 \pm 0.5$ & 1 & & 0.155 & $<0.05$ \\
\hline \multicolumn{12}{|l|}{ RDW [\%] } \\
\hline Control & $15,2 \pm 1,7$ & - & \multirow{4}{*}{0.525} & $15.0 \pm 1.3$ & - & \multirow{4}{*}{0.594} & $15,0 \pm 0.9$ & - & \multirow{4}{*}{0.85} & 0.797 & 0.743 \\
\hline Arg & $14,7 \pm 0.4$ & 0.839 & & $14.9 \pm 0.6$ & 0.973 & & $14.5 \pm 0.0$ & 0.282 & & 0.352 & 0.26 \\
\hline IHE & $12.4 \pm 0.4$ & $<0.001$ & & $12.4 \pm 0.4$ & $<0.001$ & & $12.4 \pm 0.3$ & $<0.001$ & & 0.741 & 0.618 \\
\hline Arg/IHE & $15.3 \pm 0.9$ & 0.991 & & $14.9 \pm 0.6$ & 0.975 & & $12.3 \pm 0.4$ & $<0.001$ & & 0.214 & $<0.001$ \\
\hline
\end{tabular}


Table 5. Cont.

\begin{tabular}{|c|c|c|c|c|c|c|c|c|c|c|c|}
\hline & \multicolumn{3}{|c|}{ 1st Day of Camp } & \multicolumn{3}{|c|}{ 7th Day of Camp } & \multicolumn{3}{|c|}{ 14th Day of Camp } & \multirow[b]{2}{*}{$\begin{array}{l}\text { 1st Day vs. } \\
\text { 7th Day }\end{array}$} & \multirow[b]{2}{*}{$\begin{array}{c}\text { 1st day vs. } \\
\text { 14th day }\end{array}$} \\
\hline & Mean \pm SD & $\begin{array}{l}\text { Control vs. } \\
\text { Arg, IHE or } \\
\text { Arg/IHE }\end{array}$ & $\eta^{2}$ & Mean \pm SD & $\begin{array}{l}\text { Control vs. } \\
\text { Arg, IHE or } \\
\text { Arg/IHE }\end{array}$ & $\eta^{2}$ & Mean \pm SD & $\begin{array}{l}\text { Control vs. } \\
\text { Arg, IHE or } \\
\text { Arg/IHE }\end{array}$ & $\eta^{2}$ & & \\
\hline \multicolumn{12}{|c|}{ EPO $[\mathrm{mIU} / \mathrm{mL}]$} \\
\hline Control & $3.25 \pm 0.88$ & - & \multirow{4}{*}{0.618} & $4.3 \pm 1.37$ & - & \multirow{4}{*}{0.466} & $4.84 \pm 1.17$ & - & \multirow{4}{*}{0.654} & $<0.01$ & $<0.01$ \\
\hline Arg & $3.51 \pm 0.42$ & 0.922 & & $6.08 \pm 1.04$ & $<0.05$ & & $4.40 \pm 1.68$ & 0.994 & & 0.618 & $<0.05$ \\
\hline IHE & $3.12 \pm 0.86$ & 0.99 & & $6.57 \pm 0.71$ & $<0.01$ & & $9.70 \pm 2.32$ & $<0.001$ & & $<0.01$ & $<0.001$ \\
\hline Arg/IHE & $4.62 \pm 0.8$ & $<0.01$ & & $6.49 \pm 0.73$ & $<0.01$ & & $8.13 \pm 1.62$ & $<0.001$ & & $<0.001$ & $<0.01$ \\
\hline \multicolumn{12}{|c|}{ WBC $\left[10^{3} / \mu \mathrm{L}\right]$} \\
\hline Control & $5.9 \pm 1.0$ & - & \multirow{4}{*}{0.149} & $6.7 \pm 0.7$ & - & \multirow{4}{*}{0.25} & $6.9 \pm 0.4$ & - & \multirow{4}{*}{0.173} & 0.066 & $<0.05$ \\
\hline Arg & $5.6 \pm 0.1$ & 0.774 & & $5.9 \pm 0.8$ & 0.3 & & $6.5 \pm 0.8$ & 0.957 & & 0.281 & $<0.05$ \\
\hline $\mathrm{IHE}$ & $5.0 \pm 0.3$ & 0.148 & & $5.3 \pm 0.7$ & $<0.05$ & & $6.1 \pm 0.3$ & 0.619 & & 0.114 & $<0.01$ \\
\hline Arg/IHE & $5.5 \pm 1.0$ & 0.654 & & $6.2 \pm 1.2$ & 0.699 & & $7.6 \pm 2.2$ & 0.591 & & 0.322 & $<0.05$ \\
\hline
\end{tabular}


Table 6. Lipoprotein-lipid profile.

\begin{tabular}{|c|c|c|c|c|c|c|c|c|c|c|c|}
\hline & \multicolumn{3}{|c|}{ 1st Day of Camp } & \multicolumn{3}{|c|}{ 7th Day of Camp } & \multicolumn{3}{|c|}{ 14th Day of Camp } & \multirow[b]{2}{*}{$\begin{array}{c}\text { 1st Day vs. } \\
\text { 7th Day }\end{array}$} & \multirow[b]{2}{*}{$\begin{array}{l}\text { 1st Day vs. } \\
\text { 14th Day }\end{array}$} \\
\hline & Mean \pm SD & $\begin{array}{l}\text { Control vs. } \\
\text { Arg, IHE or } \\
\text { Arg/IHE }\end{array}$ & $\eta^{2}$ & Mean \pm SD & $\begin{array}{l}\text { Control vs. } \\
\text { Arg, IHE or } \\
\text { Arg/IHE }\end{array}$ & $\eta^{2}$ & Mean \pm SD & $\begin{array}{l}\text { Control vs. } \\
\text { Arg, IHE or } \\
\text { Arg/IHE }\end{array}$ & $\eta^{2}$ & & \\
\hline \multicolumn{12}{|c|}{ TG [mg/dL] } \\
\hline Control & $97 \pm 34$ & - & \multirow{4}{*}{0.057} & $83 \pm 24$ & - & \multirow{4}{*}{0.231} & $118 \pm 42$ & - & \multirow{4}{*}{0.359} & $<0.05$ & 0.31 \\
\hline Arg & $85 \pm 24$ & 0.925 & & $76 \pm 12$ & 0.951 & & $64 \pm 4$ & $<0.01$ & & 0.331 & 0.057 \\
\hline IHE & $111 \pm 41$ & 0.898 & & $112 \pm 18$ & 0.138 & & $122 \pm 27$ & 0.995 & & 0.975 & 0.357 \\
\hline Arg/IHE & $105 \pm 50$ & 0.969 & & $78 \pm 35$ & 0.978 & & $111 \pm 32$ & 0.964 & & 0.06 & 0.764 \\
\hline \multicolumn{12}{|c|}{ TC [mg/dL] } \\
\hline Control & $196 \pm 25$ & - & \multirow{4}{*}{0.143} & $189 \pm 38$ & - & \multirow{4}{*}{0.315} & $175 \pm 19$ & - & \multirow{4}{*}{0.306} & 0.323 & $<0.05$ \\
\hline Arg & $160 \pm 47$ & 0.238 & & $138 \pm 25$ & $<0.05$ & & $148 \pm 7$ & 0.123 & & 0.097 & 0.522 \\
\hline IHE & $188 \pm 38$ & 0.976 & & $161 \pm 31$ & 0.399 & & $163 \pm 27$ & 0.789 & & $<0.05$ & $<0.05$ \\
\hline Arg/IHE & $196 \pm 41$ & 1 & & $189 \pm 34$ & 1 & & $188 \pm 30$ & 0.601 & & 0.399 & 0.359 \\
\hline \multicolumn{12}{|c|}{ LDL [mg/dL] } \\
\hline Control & $118 \pm 27$ & - & \multirow{4}{*}{0.149} & $121 \pm 33$ & - & \multirow{4}{*}{0.173} & $111 \pm 18$ & - & \multirow{4}{*}{0.059} & 0.707 & 0.232 \\
\hline Arg & $93 \pm 32$ & 0.395 & & $77 \pm 17$ & 0.555 & & $97 \pm 10$ & 0.692 & & 0.094 & 0.698 \\
\hline $\mathrm{IHE}$ & $112 \pm 38$ & 0.985 & & $103 \pm 38$ & 0.956 & & $105 \pm 37$ & 0.963 & & 0.406 & 0.386 \\
\hline Arg/IHE & $128 \pm 35$ & 0.913 & & $157 \pm 117$ & 0.664 & & $112 \pm 30$ & 0.999 & & 0.432 & 0.129 \\
\hline \multicolumn{12}{|c|}{ HDL $[\mathrm{mg} / \mathrm{dL}]$} \\
\hline Control & $64 \pm 43$ & - & \multirow{4}{*}{0.094} & $51 \pm 11$ & - & \multirow{4}{*}{0.114} & $53 \pm 10$ & - & \multirow{4}{*}{0.188} & 0.234 & 0.76 \\
\hline Arg & $50 \pm 13$ & 0.716 & & $45 \pm 9$ & 0.675 & & $53 \pm 5$ & 0.996 & & 0.182 & 0.47 \\
\hline IHE & $45 \pm 10$ & 0.498 & & $56 \pm 12$ & 0.787 & & $48 \pm 7$ & 0.667 & & $<0.01$ & $<0.05$ \\
\hline Arg/IHE & $47 \pm 7$ & 0.493 & & $49 \pm 7$ & 0.998 & & $45 \pm 8$ & 0.176 & & $<0.05$ & 0.641 \\
\hline \multicolumn{12}{|c|}{ Non-HDL [mg/dL] } \\
\hline Control & $132 \pm 44$ & - & \multirow{4}{*}{0.126} & $138 \pm 36$ & - & \multirow{4}{*}{0.312} & $122 \pm 15$ & - & \multirow{4}{*}{0.385} & 1 & 0.454 \\
\hline Arg & $110 \pm 35$ & 1 & & $92 \pm 17$ & $<0.05$ & & $95 \pm 2$ & 0.105 & & 0.084 & 0.298 \\
\hline $\mathrm{IHE}$ & $143 \pm 42$ & 1 & & $106 \pm 39$ & 0.234 & & $116 \pm 28$ & 0.951 & & $<0.05$ & $<0.001$ \\
\hline $\mathrm{Arg} / \mathrm{IHE}$ & $149 \pm 40$ & 1 & & $139 \pm 31$ & 1 & & $143 \pm 33$ & 0.215 & & 0.205 & 0.313 \\
\hline
\end{tabular}

Abbreviations: Arg, arginine supplementation; IHE, intermittent hypoxic exposure; Arg/IHE, arginine supplementation and intermittent hypoxic exposure; TG, triglycerides; TC,

total cholesterol; LDL, low-density lipoproteins; HDL, high-density lipoproteins; non-HDL, cholesterol calculated by subtracting the HDL value from a TC; $\eta^{2}$ is a measure of effect size.

Data in columns whose names begin with "Control" show the $p$-values of the Tukey's post-hoc tests of the univariate one-way ANOVA examining, separately, each dependent variable.

The last two columns show the $p$-values of the t-Student test or the Wilcoxon nonparametric test (if the normality assumption is violated). 


\section{Discussion}

Skeletal muscle regeneration is a complex event that includes changes in generation of reactive and oxygen species, interactions between skeletal muscle and the immune system as well as satellite cells activation [18]. In sports medicine, the efficiency of regenerative processes is decisive for athletes' health and physical performance. Therefore, new therapies are being sought to modify the cascade of injury-repair-regeneration of skeletal muscles. In many cases, regeneration-stimulating methods are implemented into clinical medicine to improve functional abilities in patients awaiting surgical interventions or suffering from chronic illnesses such as cardiovascular and rheumatic diseases $[4,8,13,19-22]$. $\mathrm{NO}$ and $\mathrm{H}_{2} \mathrm{O}_{2}$ production is known to increase dramatically in injured skeletal muscle $[18,23]$. In addition, previous studies have shown that persistent inflammation after exercise-induced muscle damage is accompanied by reduced $\mathrm{NO}$ bioavailability and excessive $\mathrm{H}_{2} \mathrm{O}_{2}$ concentration [18,24-26]. In the present study, intensive sport training significantly elevated NO and $\mathrm{H}_{2} \mathrm{O}_{2}$ concentrations but lowered $\mathrm{NO} / \mathrm{H}_{2} \mathrm{O}_{2}$ ratio, which indicates $\mathrm{H}_{2} \mathrm{O}_{2}$ overproduction compared to NO. Hypoxic exposure enhanced $\mathrm{H}_{2} \mathrm{O}_{2}$ concentration on the 7th day and $\mathrm{NO}$ level on the 14 th day of training camp in IHE and Arg/IHE. A large number of studies have demonstrated that intermittent hypoxia increases the production of both molecules in a variety of model systems, including cells, blood vessels, muscles and isolated hearts [27-31]. Under conditions which amplify or prolong the initial inflammatory response, manifested by CRP increase, muscle damage can be considerably increased by $\mathrm{NO}$ and $\mathrm{H}_{2} \mathrm{O}_{2}$ produced in neutrophils and macrophages by inducible nitric oxide synthase (iNOS) and NADPH oxidase (NOX). Hypoxia enhances iNOS expression in pro-inflammatory macrophages M1 which, having reached their peak concentration in injured and regenerating muscle, are then replaced by a population of M2 macrophages that can attenuate the inflammatory response and promote tissue repair [18]. Some reports have suggested that endothelial NOS expression is similarly elevated in hypoxia-exposed animals [32]. In or study, skeletal muscle damage was the primary cause of $\mathrm{NO}$ and $\mathrm{H}_{2} \mathrm{O}_{2}$ release from active immune cells. The highest levels of $\mathrm{NO}$ and $\mathrm{H}_{2} \mathrm{O}_{2}$ were observed in subjects exposed to hypoxia and who demonstrated the highest CK activity $>900$ IU/L. This increase in $\mathrm{NO}$ and $\mathrm{H}_{2} \mathrm{O}_{2}$ levels strongly correlated with $\mathrm{CK}$ activity. Total CK activity is a widely used measurement in monitoring of the training load, physical efficacy and overtraining [17,33]. Morris et al. [34] demonstrated that muscle damage biomarkers increased over time and exceeded the normal reference ranges at moderate altitude (hyperbaric hypoxia), indicating cell damage pathology. Hypoxia impairs injured muscles rebuilding in patients with chronic obstructive pulmonary disease and peripheral arterial disease, but it has a positive effect on the muscle regenerative capacity in athletes $[7,35]$. The high dose of oral arginine, applied in our study, did not have any effect on NO and $\mathrm{H}_{2} \mathrm{O}_{2}$ production and muscle damage provoked by intensive training and hypoxic exposure. Similar observations have recently been reported by Alvares et al. [36], Forbes and Bell [37], Forbes et al. [38], Meirelles and Matsuura [39] and Meirelle et al. [40]. Studies in human isolated muscle and myotube culture have demonstrated that $\mathrm{NO}$ and $\mathrm{H}_{2} \mathrm{O}_{2}$ are key regulators of pre- and posttranslational signalling events leading to cytokines, heat-stress proteins and growth factors synthesis [41]. The growth factors especially involved in myogenesis include HGF, IGF-1, PDGF ${ }^{\mathrm{BB}}$, VEGF and BDNF, which are released from leucocytes and muscle cells within a few hours after muscle damage and then secreted from other tissues during the following few days. The timing and availability of these growth factors, as well as their receptors density on or within the myogenic satellite cells, are critical mediators in the regenerative process [42]. In our study, the changes in circulating growth factors proceeded differently in time following sports training, arginine intake and/or hypoxic exposure; however, all the growth factors were found to be related to $\mathrm{NO}$ and $\mathrm{H}_{2} \mathrm{O}_{2}$ generation (Table 4). Hypoxic exposure was observed to elevate growth factors levels, except for BDNF, which significantly decreased on the 7th and 14th days of the training camp. The changes were more pronounced when arginine with IHE were used, especially for IGF-1 and VEGF. The value $\eta^{2}$ indicated that arginine and/or IHE administration produced the strongest effect on IGF-1 in comparison with other growth factors. According to Oh et al. [12] arginine promotes the synthesis and secretion of IGF-1 from hepatocytes through the mitogen-activated protein 
kinases (MAPK) cascades that are central signalling pathways and regulate a wide variety of cellular processes, including proliferation, differentiation, apoptosis and stress response. The authors showed dual function of arginine in cellular processes. Firstly, arginine directly activated MAPK signalling cascades, as a short-term effect; secondly, it induced IGF-1 mRNA expression and subsequent secretion, as seen via a long-term treatment. Arginine transport into endothelial cells is augmented by VEGF, and this effect can be modulated by hypoxia $[43,44]$. VEGF improves skeletal muscle repair through modulation of angiogenesis; however, recent studies concerning therapeutic vascularization have demonstrated that the mechanism is regulated by PDGF $^{\mathrm{BB}}$ [45]. In our study, the highest levels of VEGF and $P D G F^{B B}$ were observed in the group where simultaneous use of arginine and hypoxia exposure were applied.

The regenerative process requires multiple factors to work in a coordinated way in order to restore tissue metabolic functionality. In our study, changes in $\mathrm{NO}$ and $\mathrm{H}_{2} \mathrm{O}_{2}$ caused by simultaneous Arg and IHE application were demonstrated to be associated most significantly with circulating IGF-1 and HGF, and further on with PDGF ${ }^{\mathrm{BB}}$ and BDNF (Table 4). HGF has been proven to increase myogenic satellite cells migration to the site of injury and to play a prominent role in regulation of early phases of muscle regeneration. Its release from the muscle extracellular matrix is initially mediated via NO release after mechanical or injury-induced signals [46]. The BDNF, in turn, is the circulating factor which deserves special attention. This growth factor is part of the neurotrophic family and is responsible for the viability and functioning of a variety of neuronal subtypes within the brain. In skeletal muscle, BDNF is accountable for proliferation and differentiation of satellite cells as well as growth of the myofibers [47]. The available data show that almost $70-80 \%$ of circulating BDNF come from the brain and $25 \%$ from contracting muscles [48,49]. In this study, a decrease in BDNF concentration following hypoxic exposure was observed at a similar level, approx. 40\%, in both IHE and Arg/IHE groups. To date, the mechanism of hypoxia effect on the central nervous system has been poorly investigated. Some data suggest that hypoxic exposure reduces cognitive functions and modifies central motor command [50,51]. However, Piotrowicz et al. [52] recently demonstrated that neurotrophins, which are considered as brain damage markers, were not affected by hypoxic conditions, which proves IHE safety for the central nervous system.

$\mathrm{NO}$ and $\mathrm{H}_{2} \mathrm{O}_{2}$ are involved in signal transduction pathways as part of the $\mathrm{O}_{2}$-sensing mechanism stabilizing transcription factor HIF-1 and regulating erythropoietin expression. EPO regulates the process of haematopoiesis, stabilizes vascular integrity, increases the number of endothelial cells and protects these cells against ischemia and apoptosis [52,53]. According to Jia et al. [54] EPO contributes directly to myoblast proliferation and survival, leading to muscle regeneration and repair. The EPO expression during hypoxia is more dependent on changes in $\mathrm{H}_{2} \mathrm{O}_{2}$, whereas in non-hypoxic conditions it is related to NO, pro-inflammatory cytokines IL- $\beta$ and TNF $\alpha$ as well as growth factors [55]. In this study, hypoxic exposure, alone or with arginine intake, was found to have a significant impact on serum EPO level in relation to $\mathrm{H}_{2} \mathrm{O}_{2}$ and $\mathrm{NO}$ during a 14-day observation. It has been described that HIF-1 transcriptional activity and EPO expression are achieved through two parallel mechanisms, i.e., a decrease in $\mathrm{O}_{2}$-dependent hydroxylation of HIF-1 and S-nitrosylation of HIF-1 pathway components [30]. Beleslin-Cokic et al. [56] provided evidence that hypoxia and EPO increased the endothelial cells capacity of NO production.

The mechanisms involved in the generation of reactive oxygen and nitrogen species are critical for endothelial function [30]. The $\mathrm{NO}$ and $\mathrm{H}_{2} \mathrm{O}_{2}$ overproduction as well as nitration of many proteins cause a decrease of enzyme activity, disrupt metabolism and cellular detoxification, impair cytoskeletal organization and ultimately contribute to the cytotoxic effects of peroxynitrite. Interestingly, in this study, arginine and/or hypoxic exposure was observed to induce a decrease in non-HDL by approx. $20 \%$ on the 7 th and 14 th days compared to the 1 st day of sports training. Other elements of lipid profile tended to decrease when compared to controls. According to Bailey et al. [4] and Mallet et al. [57], intermittent hypoxic exposure increases cardiovascular resistance to ischemia-reperfusion stress and can be safely used clinically to protect subjects with developing coronary disease or those awaiting 
cardiac procedures. In sport, intermittent hypoxic exposure is commonly used to increase physical performance. However, our study demonstrated that IHE alone or in combination with arginine can simultaneously enhance regenerative capacity of skeletal muscle and protect athletes from endothelial dysfunction, especially the athletes participating in sports that include strength elements.

\section{Conclusions}

In this study we demonstrated for the first time that intermittent hypoxic exposure and high arginine intake collectively contribute to the release of mediators that regulate the injury-repair-regeneration of skeletal muscles and endothelium. Therefore, simultaneous application of IHE and arginine seems to have favourable and therapeutic potential to modulate the myogenesis and angiogenesis, especially in athletes undergoing strenuous training schedule. However, the transfer of hypoxic exposure with arginine intake to a clinical setting to enhance skeletal muscles repair or to reduce an endothelial dysfunction requires further studies.

\section{Limitations}

The limitations of the study include a relatively small number of subjects and no continuation of experiment after the training camp; however, it proved sufficient to show a protective effect of hypoxic exposure and arginine intake in elite athletes typically engaged in very high-intensity exercise training. Moreover, few epidemiologic and physiologic observations in athletes make it difficult to explain the impact of simultaneous application of IHE and arginine on the tissue regeneration.

Author Contributions: A.Z.-L. and M.C., conception and design, analysis and interpretation of the data, critical review and approval of the final version submitted for publication. A.G., statistical analysis, critical review and approval of the final version submitted for publication. E.W.-G., A.T. and N.H., drafting of the paper, critical review and approval of the final version submitted for publication. A.K. conception and design, blood sample collection and analysis of the data. All authors have read and agreed to the published version of the manuscript.

Funding: This work was supported by the National Science Centre Poland [No. N/NZ7/05282] and the statutory funds from the University of Zielona Gora [No. 222267/E-545/S/2019].

Conflicts of Interest: The authors declare no conflict of interest.

\section{References}

1. Filippin, L.I.; Cuevas, M.J.; Lima, E.; Marroni, N.P.; Gonzalezgallego, J.; Xavier, R.M. Nitric oxide regulates the repair of injured skeletal muscle. Nitric Oxide 2011, 24, 43-49. [CrossRef]

2. Kuang, S.; Gillespie, M.A.; Rudnicki, M.A. Niche regulation of muscle satellite cell self-renewal and differentiation. Cell Stem. Cell 2008, 2, 22-31. [CrossRef] [PubMed]

3. Tengan, C.H.; Rodrigues, G.S.; Godinho, R.O. Nitric oxide in skeletal muscle: Role on mitochondrial biogenesis and function. Int. J. Mol. Sci. 2012, 13, 17160-17184. [CrossRef] [PubMed]

4. Bailey, D.M.; Davies, B.; Baker, J. Training in hypoxia: Modulation of metabolic and cardiovascular risk factors in men. Med. Sci. Sports Exerc. 2000, 32, 1058-1066. [CrossRef] [PubMed]

5. Czuba, M.; Bril, G.; Ploszczyca, K.; Piotrowicz, Z.; Chalimoniuk, M.; Roczniok, R.; Zembron-Lacny, A.; Gerasimuk, D.; Langfort, J. Intermittent hypoxic training at lactate threshold intensity improves aiming performance in well-trained biathletes with little change of cardiovascular variables. Biomed Res. Int. 2019. [CrossRef] [PubMed]

6. Haufe, S.; Wiesner, S.; Engeli, S.; Luft, F.C.; Jordan, J. Influence of normobaric hypoxia training on metabolic risk markers in human subjects. Med. Sci. Sports Exerc. 2008, 40, 1939-1944. [CrossRef]

7. Chaillou, T.; Lanner, J.T. Regulation of myogenesis and skeletal muscle regeneration: Effects of oxygen levels on satellite cell activity. FASEB J. 2016, 30, 3929-3941. [CrossRef]

8. Savla, J.J.; Levine, B.D.; Sadek, H.A. The effect of hypoxia on cardiovascular disease: Friend or foe? High. Alt. Med. Biol. 2018, 19, 124-130. [CrossRef]

9. Barbieri, E.; Sestili, P. Reactive oxygen species in skeletal muscle signaling. J. Signal. Transduct. 2012, $2012,982794$. [CrossRef] [PubMed] 
10. Nakada, Y.; Canseco, D.C.; Thet, S.; Abdisalaam, S.; Asaithamby, A.; Santos, C.X.; Shah, A.M.; Zhang, H.; Faber, J.E.; Kinter, M.T.; et al. Hypoxia induces heart regeneration in adult mice. Nature 2017, 541, 222-227. [CrossRef]

11. Böger, R.H. The pharmacodynamics of L-arginine. J. Nutr. 2007, 137, 1650S-1655S. [CrossRef] [PubMed]

12. Oh, H.S.; Oh, S.K.; Lee, J.S.; Wu, C.; Lee, S.J. Effects of L-arginine on growth hormone and insulin-like growth factor 1. Food Sci. Biotechnol. 2017, 26, 1749-1754. [CrossRef]

13. Curran, J.N.; Winter, D.C.; Bouchier-Hayes, D. Biological fate and clinical implications of arginine metabolism in tissue healing. Wound Rep. Reg. 2006, 14, 376-386. [CrossRef]

14. Filippin, L.I.; Moreira, A.J.; Marroni, N.P.; Xavier, R.M. Nitric oxide and repair of skeletal muscle injury. Nitric Oxide 2009, 21, 157-163. [CrossRef] [PubMed]

15. Hinckson, E.A.; Hamlin, M.J.; Wood, M.R.; Hopkins, W.G. Game performance and intermittent hypoxic training. Br. J. Sports Med. 2007, 41, 537-539. [CrossRef] [PubMed]

16. Ferguson, C.J. An Effect Size Primer: A Guide for Clinicians and Researchers. Prof. Psychol. Res. Pract. 2009, 40, 532-538. [CrossRef]

17. Zembron-Lacny, A.; Ziemann, E.; Zurek, P.; Hübner-Wozniak, E. Heat shock protein 27 response to wrestling training in relation to the muscle damage and inflammation. J. Strength Cond. Res. 2017, 3, 1221-1228. [CrossRef]

18. Tidball, J.G. Regulation of muscle growth and regeneration by the immune system. Nat. Rev. Immunol. 2017, 17, 165-178. [CrossRef]

19. Ambrose, K.R.; Golightly, Y.M. Physical exercise as non-pharmacological treatment of chronic pain: Why and when. Best Pract. Res. Clin. Rheumatol. 2015, 29, 120-130. [CrossRef]

20. Chang, J.C.; Lien, C.F.; Lee, W.S.; Chang, H.R.; Hsu, Y.C.; Luo, Y.P.; Jeng, J.R.; Hsieh, J.C.; Yang, K.T. Intermittent Hypoxia Prevents Myocardial Mitochondrial $\mathrm{Ca}^{2+}$ Overload and Cell Death during Ischemia/Reperfusion: The Role of Reactive Oxygen Species. Cells 2019. [CrossRef]

21. Dobson, J.L.; McMillan, J.; Li, L. Benefits of exercise intervention in reducing neuropathic pain. Front. Cell Neurosci. 2014, 8, 102. [CrossRef] [PubMed]

22. Ghaly, A.; Marsh, D. Ischaemia-reperfusion modulates inflammation and fibrosis of skeletal muscle after contusion injury. Int. J. Exp. Pathol. 2010, 91, 244-255. [CrossRef] [PubMed]

23. Sakurai, T.; Kashimura, O.; Kano, Y.; Ohno, H.; Ji, L.L.; Izawa, T.; Best, T.M. Role of nitric oxide in muscle regeneration following eccentric muscle contractions in rat skeletal muscle. J. Physiol. Sci. 2013, 63, 263-270. [CrossRef] [PubMed]

24. Filippin, L.I.; Cuevas, M.J.; Lima, E.; Marroni, N.P.; Gonzalez-Gallego, J.; Xavier, R.M. The role of nitric oxide during healing of trauma to the skeletal muscle. Inflamm. Res. 2011, 60, 347-356. [CrossRef]

25. Soneja, A.; Drews, M.; Malinski, T. Role of nitric oxide, nitroxidative and oxidative stress in wound healing. Pharmacol. Rep. 2005, 57, 108-119.

26. Zembron-Lacny, A.; Tylutka, A.; Zeromska, A.; Kasperska, A.; Wolny-Rokicka, E. Does high volume of exercise training increase aseptic vascular inflammation in male athletes? Am. J. Men's Health 2019, 13. [CrossRef]

27. Ding, H.L.; Zhu, H.F.; Dong, J.W.; Zhu, W.Z.; Yang, W.W.; Yang, H.T.; Zhou, Z.N. Inducible nitric oxide synthase contributes to intermittent hypoxia against ischemia/reperfusion injury. Acta Pharmacol. Sin. 2005, 26, 315-322. [CrossRef]

28. Grebe, A.; Hoss, F.; Latz, E. NLRP3 inflammasome and the IL-1 pathway in atherosclerosis. Circ. Res. 2018, 122, 1722-1740. [CrossRef]

29. Strijdom, H.; Muller, C.; Lochner, A. Direct intracellular nitric oxide detection in isolated adult cardiomyocytes: Flow cytometric analysis using the fluorescent probe, diaminofluorescein. J. Mol. Cell. Cardiol. 2004, 37, 897-902. [CrossRef]

30. Strijdom, H.; Jacobs, S.; Hattingh, S.; Page, C.; Lochner, A. Nitric oxide production is higher in rat cardiac microvessel endothelial cells than ventricular cardiomyocytes in baseline and hypoxic conditions: A comparative study. FASEB J. 2006, 20, 314-316. [CrossRef]

31. Vogt, M.; Hoppeler, H. Is hypoxia training good for muscles and exercise performance? Prog. Cardiovasc. Dis. 2010, 52, 525-533. [CrossRef] [PubMed] 
32. Kolár, F.; Szárszoi, O.; Neckář, J.; Pecháňová, O.; Miková, D.; Hampl, V.; Oštádal, B. Role of nitric oxide and reactive oxygen species in reperfusion-induced arrhythmias and cardioprotection in chronically hypoxic rat. hearts. Physiol. Res. 2003, 52, 52.

33. Brancaccio, P.; Lippi, G.; Maffulli, N. Biochemical markers of muscular damage. Clin. Chem. Lab. Med. 2010, 48, 757-767. [CrossRef] [PubMed]

34. Morris, K.L.; Widstrom, L.; Goodrich, J.; Poddar, S.; Rueda, M.; Holliday, M.; San Millian, I.; Byrnes, W.C. A Retrospective Analysis of Collegiate Athlete Blood Biomarkers at Moderate Altitude. J. Strength Cond. Res. 2019, 33, 2913-2919. [CrossRef] [PubMed]

35. Hoppeler, H.; Vogt, M. Muscle tissue adaptations to hypoxia. J. Exp. Biol. 2001, 204, 3133-3139. [PubMed]

36. Alvares, T.S.; Conte-Junior, C.A.; Silva, J.T.; Paschoalin, V.M. L-arginine does not improve biochemical and hormonal response in trained runners after 4 weeks of supplementation. Nutr. Res. 2014, 34, 31-39. [CrossRef]

37. Forbes, S.C.; Bell, G.J. The acute effects of a low and high dose of oral L-arginine supplementation in young active males at rest. Appl. Physiol. Nutr. Metab. 2011, 36, 405-411. [CrossRef]

38. Forbes, S.C.; Harber, V.; Bell, G.J. The acute effects of L-arginine on hormonal and metabolic responses during submaximal exercise in trained cyclists. Int. J. Sport Nutr. Exerc. Metab. 2013, 23, 369-377. [CrossRef]

39. Meirelles, C.M.; Matsuura, C. Acute supplementation of L-arginine affects neither strength performance nor nitric oxide production. J. Sports Med. Phys. Fit. 2018, 58, 216-220.

40. Meirelles, C.M.; Matsuura, C.; Silva, R.S., Jr.; Guimarães, F.F.; Gomes, P.S.C. Acute effects of l-arginine supplementation on oxygen consumption kinetics and muscle oxyhemoglobin and deoxyhemoglobin during treadmill running in male adults. Int. J. Exerc. Sci. 2019, 12, 444-455.

41. Sies, H.; Jones, D.P. Reactive oxygen species (ROS) as pleiotropic physiological signalling agents. Nat. Rev. Mol. Cell. Biol. 2020. [CrossRef] [PubMed]

42. Zembron-Lacny, A.; Krzywański, J.; Ostapiuk-Karolczuk, J.; Kasperska, A. Cell and molecular mechanisms of regeneration and reorganization of skeletal muscles. Ortop. Traumatol. Rehabil. 2012, 14, 1-11. [CrossRef] [PubMed]

43. Breen, E.; Tang, K.; Olfert, M.; Knapp, A.; Wagner, P. Skeletal muscle capillarity during hypoxia: VEGF and its activation. High Alt. Med. Biol. 2008, 9, 158-166. [CrossRef] [PubMed]

44. Shashar, M.; Chernichovski, T.; Pasvolsky, O.; Levi, S.; Grupper, A.; Hershkovitz, R.; Weinstein, T.; Schwartz, I.F. Vascular Endothelial Growth Factor Augments Arginine Transport and Nitric Oxide Generation via a KDR Receptor Signaling Pathway. Kidney Blood Press. Res. 2017, 42, 201-208. [CrossRef]

45. Gianni Barrera, R.; Di Maggio, N.; Melly, L.; Burger, M.G.; Mujagic, E.; Gürke, L.; Schaefer, D.J.; Banfi, A. Therapeutic vascularization in regenerative medicine. Stem Cells Transl. Med. 2020, 9, 433-444. [CrossRef] [PubMed]

46. Anderson, J.E. Hepatocyte growth factor and satellite cell activation. Adv. Exp. Med. Biol. 2016, 900, 1-25.

47. Pedersen, B.K.; Pedersen, M.; Krabbe, K.S.; Bruunsgaard, H.; Matthews, V.B.; Febbraio, M.A. Role of exercise-induced brain-derived neurotrophic factor production in the regulation of energy homeostasis in mammals. Exp. Physiol. 2009, 94, 1153-1160. [CrossRef]

48. Ogborn, D.I.; Gardiner, P.F. Effects of exercise and muscle type on BDNF, NT-4/5, and TrKB expression in skeletal muscle. Muscle Nerve 2010, 41, 385-391. [CrossRef] [PubMed]

49. Rasmussen, P.; Brassard, P.; Adser, H.; Pedersen, M.V.; Leick, L.; Hart, E.; Secher, N.H.; Pedersen, B.K.; Pilegaard, H. Evidence for a release of brain-derived neurotrophic factor from the brain during exercise. Exp. Physiol. 2009, 94, 1062-1069. [CrossRef]

50. Lieberman, P.; Protopapas, A.; Reed, E.; Youngs, J.W.; Kanki, B.G. Cognitive defects at altitude. Nature 1994, 372, 325. [CrossRef]

51. Amann, M.; Romer, L.M.; Subudhi, A.W.; Pegelow, D.F.; Dempsey, J.A. Severity, of arterial hypoxaemia affects the relative contributions of peripheral muscle fatigue to exercise performance in healthy humans. J. Physiol. 2007, 581, 389-403. [CrossRef] [PubMed]

52. Piotrowicz, Z.; Chalimoniuk, M.; Płoszczyca, K.K.; Czuba, M.; Langfort, J. Acute normobaric hypoxia does not affect the simultaneous exercise-induced increase in circulating BDNF and GDNF in young healthy men: A feasibility study. PLoS ONE 2019, 14, e0224207. [CrossRef] [PubMed]

53. Suresh, S.; Rajvanshi, P.K.; Noguchi, C.T. The many facets of erythropoietin physiologic and metabolic response. Front. Physiol. 2019, 10, 1534. [CrossRef] [PubMed] 
54. Jia, Y.; Suzuki, N.; Yamamoto, M.; Gassmann, M.; Noguchi, C.T. Endogenous erythropoietin signaling facilitates skeletal muscle repair and recovery following pharmacologically induced damage. FASEB J. 2012, 26, 2847-2858. [CrossRef]

55. Heeschen, C.; Aicher, A.; Lehmann, R.; Fichtlscherer, S.; Vasa, M.; Urbich, C.; Mildner-Rihm, C.; Martin, H.; Zeiher, A.M.; Dimmeler, S. Erythropoietin is a potent physiologic stimulus for endothelial progenitor cell mobilization. Blood 2003, 102, 1340-1346. [CrossRef]

56. Beleslin-Cokic, B.B.; Cokic, V.P.; Yu, X.; Weksler, B.B.; Schechter, A.N.; Noguchi, C.T. Erythropoietin and hypoxia stimulate erythropoietin receptor and nitric oxide production by endothelial cells. Blood 2004, 104, 2073-2080. [CrossRef]

57. Mallet, R.T.; Manukhina, E.B.; Ruelas, S.S.; Caffrey, J.L.; Downey, H.F. Cardioprotection by intermittent hypoxia conditioning: Evidence, mechanisms, and therapeutic potential. Am. J. Physiol. Heart Circ. Physiol. 2018, 315, H216-H232. [CrossRef]

(C) 2020 by the authors. Licensee MDPI, Basel, Switzerland. This article is an open access article distributed under the terms and conditions of the Creative Commons Attribution (CC BY) license (http://creativecommons.org/licenses/by/4.0/). 